\title{
Population dynamics of the bivalves Gari solida, Semele solida and Protothaca thaca from a small bay in Chile at $36^{\circ} \mathrm{S}^{*}$
}

\author{
H.-Jörg Urban ${ }^{1}$, Bernardita Campos ${ }^{2}$ \\ 'Alfred-Wegener-Institut für Polar- und Meeresforschung, Columbusstr., D-27568 Bremerhaven, Germany \\ ${ }^{2}$ Instituto de Oceanología, Universidad de Valparaíso, Casilla 13-D, Viña del Mar, Chile
}

\begin{abstract}
Gari solida (Gray, 1828), Semele solida (Gray, 1828) and Protothaca thaca (Molina, 1782) are dominant members of the shallow-water, soft-bottom communities of the Peruvian-Chilean upwelling system. They are exploited commercially all over their distribution range. Reproduction, growth, mortality, and production of these species were studied from a small bay in Chile at $36^{\circ} \mathrm{S}$. Results indicate an annual reproductive cycle with a short spawning season. The growth parameters of the non-oscillating von Bertalanfy function were: $G$. solida: $L_{\infty}=89.6 \mathrm{~mm}, K=0.307 \mathrm{yr}^{-1}, t_{0}=0.354$ $\mathrm{yr}^{-1}$; S. solida: $L_{\infty}=78.0 \mathrm{~mm}, K=0.297 \mathrm{yr}^{-1}, t_{0}=0.374 \mathrm{yr}^{-1} ; P$. thaca: $L_{\infty}=82.2 \mathrm{~mm}, K=0.174 \mathrm{yr}^{-1}, t_{0}=$ $0.069 \mathrm{yr}^{-1}$. Production estimates agree very well with data of other members of the Tellinacea and Veneracea taken from the literature. Annual somatic and gonad production amounted to 27.6 and 56.0 (G. solida), 4.8 and 8.6 ( $S$. solida) and 16.9 and 14.5 ( $P$. thaca) $\mathrm{g}$ AFDW $\mathrm{m}^{-2}$. The following production/biomass $(P / \bar{B})$ ratios were obtained: for $G$. solida 0.334 , for $S$. solida 0.188 and for P. thaca 0.269 . Total mortality was estimated as 0.842 (G. solida), 0.924 ( $S$. solida) and $0.584 \mathrm{yr}^{-1}$ ( $P$. thaca). The influence of latitudinal gradients on reproductive strategies is related to the results on reproduction cycles. Production and mortality estimates are discussed in relation to the influence of the fishery.
\end{abstract}

KEY WORDS: Gari solida - Semele solida - Protothaca thaca - Bivalvia - Population dynamics - Reproduction - Growth $\cdot$ Mortality $\cdot$ Production $\cdot$ Chile

\section{INTRODUCTION}

Owing to upwelling, the marine ecosystem off Peru and Chile is one of the most productive in the world (Ryther 1969). High primary production sustains a high level of secondary production. Besides a well-developed industrial exploitation of pelagic resources, a small-scale (artisanal) fishery of benthic invertebrates is of considerable importance for local consumption. The most important resource for this fishery is bivalves (mussels and clams). Approximately 10 shallow-water bivalve species are exploited commercially. However, despite their importance, little is known about the biology and ecology of these species and little information on the population dynamics is available in the literature, although this information is essential for any attempt at stock management. Therefore, in many

\footnotetext{
-Contribution no. 823 of the Alfred-Wegener-Institut für Polar- und Meeresforschung
}

areas stocks are overexploited leading to a reduction of catches.

Urban (1992) presented a comparative study on the ecology of 8 commercially exploited bivalve species. Here we deal with the population dynamics of 3 of them, Gari solida (Gray, 1828), Semele solida (Gray, 1828) and Protothaca thaca (Molina, 1782). All 3 species are infaunal burrowers in sandy substrates of the intertidal and subtidal, down to $20 \mathrm{~m}$ depth. Their geographical distribution along the South American Pacific coast is as follows: G. solida, 14 to $54^{\circ} \mathrm{S}, \mathrm{S}$. solida, 12 to $45^{\circ} \mathrm{S}$ and $P$. thaca, 12 to $45^{\circ} \mathrm{S}$ (Urban 1994a). Over the distribution range local populations are formed. Often the 3 species are found in the same habitat, as was the case in the present study. G. solida and S. solida belong to the superfamily Tellinacea, while $P$. thaca belongs to the superfamily Veneracea. Both superfamilies are members of the order Veneroida.

The aim of the present paper is to report studies on the reproduction, growth, mortality and production of 
Gari solida, S. solida and $P$. thaca from a small bay in Chile and to compare these results with data from the literature.

\section{MATERIAL AND METHODS}

Research area and sampling. The investigations were undertaken in the Bay of Dichato $\left(36^{\circ} 32^{\prime} \mathrm{S}\right.$, $\left.73^{\circ} 57^{\prime} \mathrm{W}\right)$, a small bay of approximately $12 \mathrm{~km}^{2}$ (Fig. 1). Water temperature decreases to about $12^{\circ} \mathrm{C}$ in winter and rises to $16^{\circ} \mathrm{C}$ in summer. The investigation area, especially its distribution of substrate types, is described in Urban (1994b). At least 8 subtidal populations of different bivalve species exist in this area at different places (Urban 1992). The 3 bivalve species studied here are distributed almost exclusively near the entrance of the ocean in the north-western part of the bay (Fig. 1).

Samples were taken by SCUBA divers at monthly intervals at 2 to $5 \mathrm{~m}$ depths. On each sampling all bivalves present in 5 to 10 randomly selected squares $\left(0.25 \mathrm{~m}^{2}\right)$ were collected by hand. In addition, every 2 mo, 2 or 3

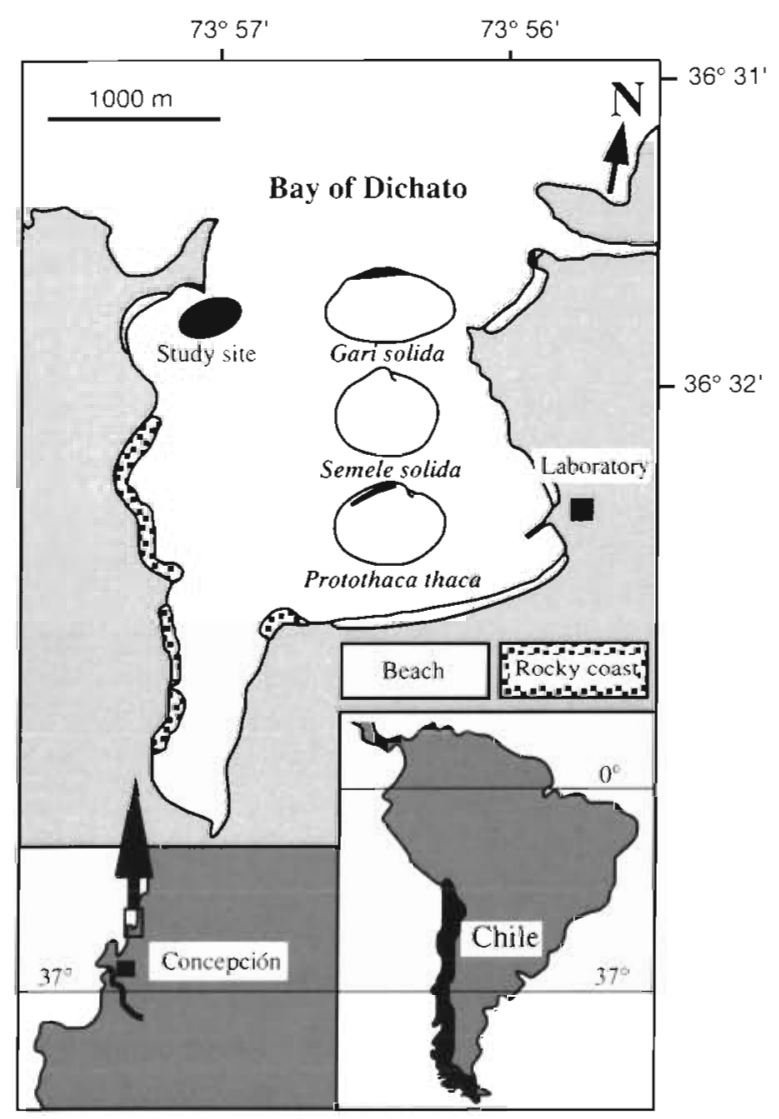

Fig. 1. Investigation area. Location of the sampling station and the names of the species studied are given sediment cores of $25 \times 25 \mathrm{~cm}$ area and $20 \mathrm{~cm}$ depth were dug out and sieved through $1 \mathrm{~mm}$ mesh to check for the presence of specimens smaller than $5 \mathrm{~mm}$ shell length, which the divers easily overlooked.

Maximum length on the anterior-posterior axis (shell length) was recorded from all individuals with vernier calipers. Sea surface temperature was recorded at each sampling. Subsamples of 30 to 40 individuals were taken from the monthly samples, and shell length and total wet weight (shell and body wet weight) were recorded. All soft parts were removed and dried at $60^{\circ} \mathrm{C}$ to constant weight for body dry weight estimations. Ash-free dry weight (AFDW) was obtained by ignition of dried soft parts at $550^{\circ} \mathrm{C}$ for $5 \mathrm{~h}$. Further subsamples were taken for histological sections of ovaries (Gari solida only) and for shell ring measurements in order to estimate growth. Sampling began in January 1991 and lasted until May 1992. However, body weight cycles and annual production were calculated for the period April 1991 to March 1992. Therefore, the monthly length-frequency distributions from these months were pooled. Total sample size for the pooled samples was 3068 individuals for G. solida, 843 for $S$. solida, and 816 for $P$. thaca. The reproductive cycle, based on histological sections, was studied for the period June 1991 to May 1992.

Reproduction. The parameters of the relationship between length and weight ( $\mathrm{Eq}$. 1) were estimated by linear regression analysis on log-transformed data. Annual body dry weight cycles for a standard individual of $50 \mathrm{~g}$ total wet weight were calculated as

$$
W=a L^{b}
$$

where $W$ is body dry weight $(\mathrm{g}), L$ is shell length $(\mathrm{mm})$ and $a$ and $b$ are constants. An F-test was used to test for significant differences of regression lines of the length weight relationships between 2 successive months.

For histological sections soft parts were fixed in Bouin's solution, dehydrated in alcohol and then embedded in paraffin wax. Sections of $8 \mu \mathrm{m}$ were stained in Harris' hematoxylin and eosin. In total 760 gonads and 2220 histological sections were prepared.

Different reproductive stages of the reproductive cycle were based on the morphological development of the germ lines in the acinus of the gonads. This parameter reflects the activity of the gametes. Five histological stages were distinguished:

Developing 1: Corresponds to the initial development of the acinus of the gonads. These are small with a rough basal membrane. Germ line principally represented by previtellogenic oocytes which stick to the wall of the acinus as well as the oogones. Oocytes which have passed through their meiotic stage show spherical and pallid germ vesicles with clear nucleolus and a basophilic cytoplasm. The large amounts of basophilic 
cytoplasm in some oocytes indicates incipient vitellogenesis. These latter oocytes can move towards the lumen as pedunculate vitellogenic oocytes, united by a fine cytoplasmatic stalk at the wall of the acinus.

Developing 2: The gonadal acinus increases in size with increasing numbers of vitellogenic oocytes sticking to the basal membrane, especially the number of the pedunculate oocytes. Free vitellogenic oocytes are found in the acinal lumen which are recognizable by (1) their prominent germ vesicles, (2) their abundant cytoplasm and (3) the development of a vitellin cover.

Ripe: The acinus is large. Free vitellogenic oocytes which fill the acinus are dominating. Germ cells clearly visible owing to a large ovoid to spherical germ vesicle with a prominent nucleolus, which typically shows a basophilic zone, and another characterized as an anfinucleolus (Raven 1961, Lucas 1971). Early germ line rarely represented by a few oogones and previtellogenic oocytes of small size.

Spent 1: Or stage of initial regression. The acinus is smaller and of irregular form indicating the beginning emission of female gametes in the stage of vitellogenic oocytes with intact germ vesicles. Germ cells which have completed their development present in low numbers, leaving free room in the acinus. Early germ line rarely present.

Spent 2: Or stage of total regression. The acinus is small with a rough basal membrane. Only few residual free oocytes (normally in the stage of degeneration) can be detected in the acinus. Normally, an intracinal tissue of somatic cells fills the acinal lumen. Early germ line represented only by a few oogones.

Growth. Annual shell growth rings on the surface of the valves of approximately 30 individuals were measured with vernier calipers. It was easy to distinguish between disturbance rings and annual rings due to the stronger and clearer appearance of the latter. Two data sets were obtained: (1) Individual growth increment data arranged as tagging recapture data with constant time intervals ( $t=1 \mathrm{yr}$ ), and (2) mean lengths for each age were calculated from all individuals to obtain agelength data. For growth estimation the non-oscillating von Bertalanfy growth function, VBGF (von Bertalanffy 1938), was used:

$$
L_{t}=L_{\infty}\left(1-\mathrm{e}^{-K\left(t-t_{0}\right)}\right)
$$

where $L_{t}$ is length at age $t_{1} L_{\infty}$ is the asymptotic length $(\mathrm{mm}), K$ is the growth constant $\left(\mathrm{Yr}^{-1}\right), t$ is the age ( $\mathrm{yr}$ ) and $t_{0}$ is the age at zero length.

Growth parameters were estimated using Fabens' (1965) method by fitting a rearranged function of the VBGF to size increment data pairs (i.e, tagging recapture data) using the Simplex algorithm:

$$
L_{2}=L_{1}+\left(L_{\infty}-L_{1}\right)\left(1-\mathrm{e}^{-K\left(t_{2}-t_{1}\right)}\right)
$$

where $L_{1}$ is the length at the beginning and $L_{2}$ the length at the end of the time interval.

With this method only $L_{\infty}$ and $K$ can be estimated. In order to estimate $t_{0}$ as well, the original VBGF (Eq. 2) was fitted to age-length data with the Simplex algorithm.

Methods of estimating growth such as those described above may lead to erroneous values of $L_{\infty}$. For example too-low values will be obtained if large individuals are missing in the tagging recapture data set. As $L_{\infty}$ and $K$ are inversely related (Pauly 1979) in such a case, erroneously high $K$-values will also be obtained. A method for calculating $L_{\infty}$ from an alternative data source (length-frequency data) is the Wetherall method (see below under methods for mortality estimations). Preliminary results of Fabens' method and the VBGF fitted to age-length data showed that $L_{\infty}$ deviated considerably from $L_{\max }$, the largest individual present in the pooled length-frequency data. Much better results were obtained with the Wetherall method, which gave values consistently a little higher than $L_{\max }$. The 2 routines for growth estimations were therefore rerun with fixed values of $L_{\infty}$, calculated after Wetherall.

Mortality. Total mortality $Z$ was calculated by the single negative exponential model:

$$
N_{t}=N_{0} \mathrm{e}^{-Z t}
$$

(where $t$ is the time and $N_{0}$ is the number of individuals at $t=0$ ) and the length-converted catch curve running the ELEFAN II routine of the 'Compleat ELEFAN' program (Gayanilo et al. 1988) on the pooled lengthfrequency data. Based on the VBGF parameter in this routine, lengths are converted to ages after the following model:

$$
N_{1} / \Delta t_{1}=N_{0}{ }^{\prime} \mathrm{e}^{-Z t_{1}}
$$

where $N_{l}$ is the number of individuals in length class $i_{1}$ $\Delta t_{i}$ is the time required to grow through this size class and $t_{1}$ is the age of the middle length class $i$. Mortality $Z$ is calculated by linear regression analysis:

$$
\log _{e}\left(N_{i} / \Delta t_{j}\right)=a+b t_{i} ; \quad Z=-b
$$

Another method, available in the routine ELEFAN II of the 'Compleat ELEFAN' program is the modified Wetherall et al. method (Pauly 1986, modified after Wetherall 1986), which obtains $L_{\infty}$ and the parameter $Z / K$ from length-frequency data. The Wetherall method rearranges Beverton \& Holt's (1956) Z-equation based on length data to a linear regression equation:

$$
\bar{L}-L^{\prime}=a+b L^{\prime} ; Z / K=-(1+b) / b ; L_{\infty}=-a / b
$$

where $\widetilde{L}$ is the mean length of individuals of length $L^{\prime}$ and longer and $L^{\prime}$ is the length for which all individuals of that length and longer are under full exploitation. 
Production. Based on the results of the annual reproduction and body weight cycles, annual gonad production ( $P_{\text {gon }}$, in $\mathrm{g}$ AFDW $\mathrm{m}^{-2}$ ) was calculated from length weight relations (Eq. 1) of the lowest body weight before and the highest body weight during the spawning season on monthly samples

$$
P_{\text {gon. }}=\sum N_{i}\left(W_{i(\text { gon.dur })}-W_{i(\text { gon.pre })}\right)
$$

where $W_{i \text { (gon dur) }}$ and $W_{\text {ligon pre) }}$ are gonad weights during and before the spawning season in length class $i$.

The length of first maturity was calculated after Eversole (1989) as $25 \%$ of the maximum length ( $\left.L_{\max }\right)$ present in the pooled length-frequency data.

Annual somatic production ( $P$, in $g$ AFDW $m^{-2}$ ) was calculated by the weight-specific growth rate method (Crisp 1984) from the mean of quantitative samples, pooled length-frequency data, the VBGF parameter and the length-weight relationship:

$$
P=\sum N_{1} W_{1} G_{1}
$$

where $N_{i}$ is the mean number of individuals $\left(\mathrm{N} \mathrm{m}^{-2}\right), W_{l}$ the mean body weight ( $g$ AFDW) in length class $i$, and $G_{i}$ the weight-specific growth rate $\left(\mathrm{yr}^{-1}\right)$ :

$$
G_{1}=b K\left[\left(L_{\infty} / L_{i}\right)-1\right]
$$

where $b$ is the exponent of the length-weight relationship (Eq. 1), $L_{\infty}$ and $K$ are VBGF parameters and $L_{1}$ is the mean length in length class $i$.

Annual mean biomass ( $\bar{B}$, in $\mathrm{g}$ AFDW m ${ }^{-2}$ ) was calculated as follows

$$
\bar{B}=\sum N_{j} W_{1}
$$

The annual $P / \bar{B}$ ratio was calculated from annual somatic production $P$ and annual mean biomass $\vec{B}$.

\section{RESULTS}

\section{Reproduction}

For Gari solida, Fig, 2 shows the overlay of annual body weight cycle and sea surface temperature as well as the reproduction cycle based on histological sections. During a short period (between November 1991 and January 1992) principally developing 2 and ripe ovaries are present while during a much longer period (June to October 1991 and February to May 1992) spent 2 and developing 1 ovaries dominate. This clearly indicates an annual reproduction cycle with a short reproductive period between October and January/February with a possible second short spawning event in March/April. The body weight cycle correlates very well with the water temperature cycle: in winter, from April to October 1991, the temperatures and body weights decline, and rise during spring and

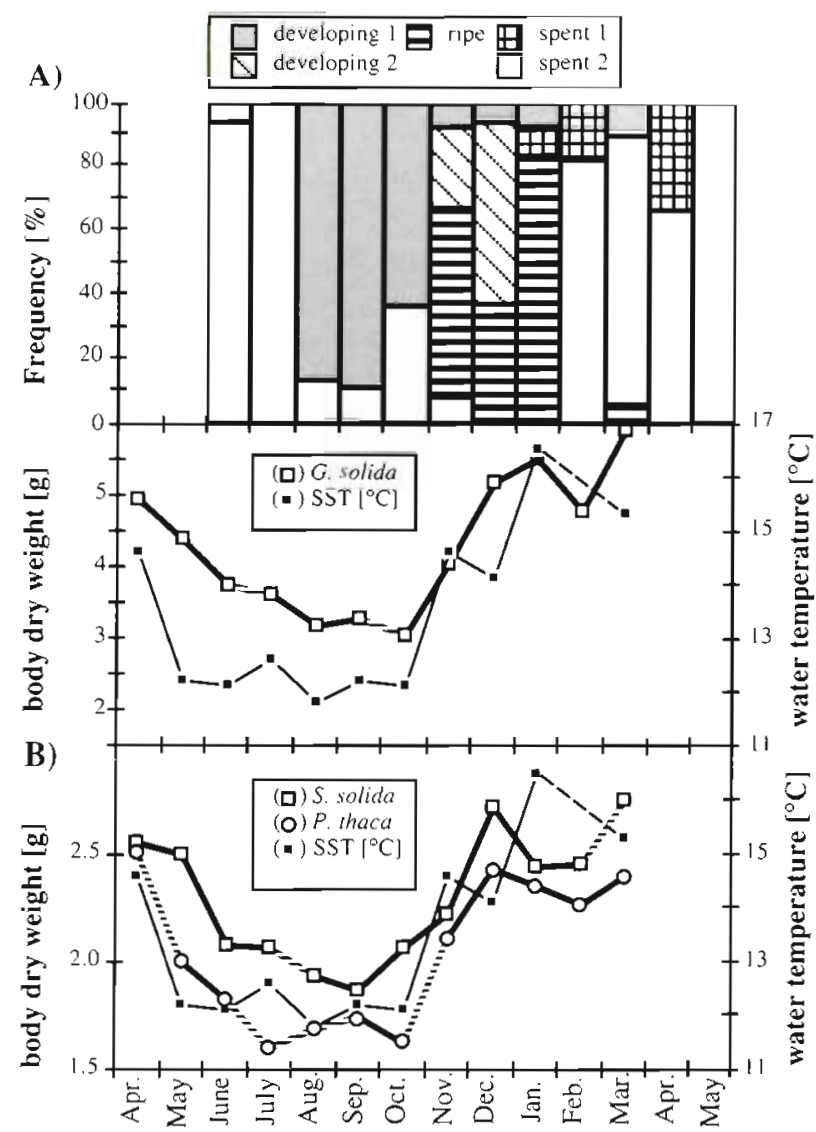

Fig. 2. (A) Gari solida. Reproductive cycle, based on histological sections of ovaries, for the period June 1991 to May 1992; and overlay of body dry weight cycle for a $50 \mathrm{~g}$ wet weight standard individual and the sea surface temperature (SST) cycle for the period April 1991 to March 1992. (B) Semele solida and Protothaca thaca. Overlay of body dry weight cycle for a $50 \mathrm{~g}$ wet weight standard individual and the SST cycle for the period April 1991 to March 1992. Solid lines (weight cycles): significant differences $(p \leq 0.05)$ between 2 successive months; broken lines: nonsignificant differences

summer from November 1991 to March 1992. High body weights therefore seem to be related to reproductive activities which might be triggered by low temperatures in winter. The body weight and water temperature cycles of Semele solida and Protothaca thaca follow the same pattern as for $G$. solida. A similar reproduction cycle for $S$. solida and $P$. thaca is therefore indicated. For $G$. solida and $S$. solida, except for 2 times (June/July, September/October and July/August, February/March, respectively), the body-weight changes between 2 successive months were significantly different $(\mathrm{p} \leq 0.05)$. For $P$. thaca significant differences were found only in the months May/June, September/October and then from November to the end of the study period (March). 
Table 1 Garl solida, Semele solida and Protothaca thaca. Parameters of the length $(\mathrm{mm})$ - body dry weight $(\mathrm{g})$ relationship for 3 Chilean bivalve species before and during the spawning season. $\log ($ Weight $)=a+b \log ($ Length $)$

\begin{tabular}{|llcccc|}
\hline Species & Month & $a$ & $b$ & $\mathrm{r}^{2}$ & $\mathrm{n}$ \\
\hline G. solida & Oct 1991 & -5.093 & 3.074 & 0.99 & 28 \\
& Jan 1992 & -4.323 & 2.792 & 0.98 & 32 \\
S. solida & Sep 1991 & -5.270 & 3.169 & 0.99 & 36 \\
& Dec 1992 & -4.525 & 2.824 & 0.98 & 31 \\
P. thaca & Oct 1991 & -6.490 & 3.957 & 0.98 & 30 \\
& Dec 1992 & -5.225 & 3.292 & 0.97 & 28 \\
& & & & & \\
\hline
\end{tabular}

Based on these results, annual gonad production was calculated as the difference between the lowest annual body weight before and the highest body weight during the spawning season by linear regression analysis for each length class, accordingly. The linear regression parameter for the length-weight relationships for the lowest and the highest body weights are given in Table 1.

\section{Growth and mortality}

The results for the VBGF parameter are given in Table 2 . With tagging recapture data, low $L_{\infty}$ - and high $K$-values were obtained, while with age-length data higher $L_{\infty}$ - and low $K$-values were obtained, owing to the inverse relationship of $L_{\infty}$ and $K$ (see 'Material and methods'). However, estimated with fixed $L_{\infty}$-values after Wetherall (Table 3 ), the $K$-values are very similar. Non-oscillating VBGF growth curves, calculated with these mean $K$-values from both data sets, are shown together with age-length data in Fig. 3. The fit of growth curves and data is very good. Fig. 4 shows the size-converted catch curves and the obtained estimates of $Z$. These values are compared with the $Z$ -
Table 3. Gari solida, Semele solida and Protothaca thaca. $Z$-values (mortality) estimated with the catch curve method $\left(Z_{c i}\right)$ and after Wetherall (1986) $\left(Z_{\text {weth }}\right)$. Also given are the VBGF parameters used as input data for the catch curve method: $L_{\infty}$ (estimated after Wetherall), $K$ and $t_{0}$ from Fig. 3

\begin{tabular}{|lccccc|}
\hline Species & $Z_{\mathrm{cc}}$ & $Z_{\text {weth }}$ & $L_{\infty}$ & $K$ & $t_{0}$ \\
\hline G. solida & 0.846 & 0.838 & 89.6 & 0.307 & 0.354 \\
S. solida & 0.916 & 0.931 & 78.0 & 0.297 & 0.374 \\
P. thaca & 0.628 & 0.540 & 82.2 & 0.174 & 0.069 \\
\hline
\end{tabular}

values estimated after Wetherall in Table 3. For Gari solida and Semele solida the different values agree very well $(0.85 / 0.84$ and $0.92 / 0.93$, respectively), while in Protothaca thaca a higher variability can be observed $(0.63 / 0.54)$. The results indicate slightly higher growth and mortality rates for $G$. solida and $S$. solida and the reverse for $P$. thaca.

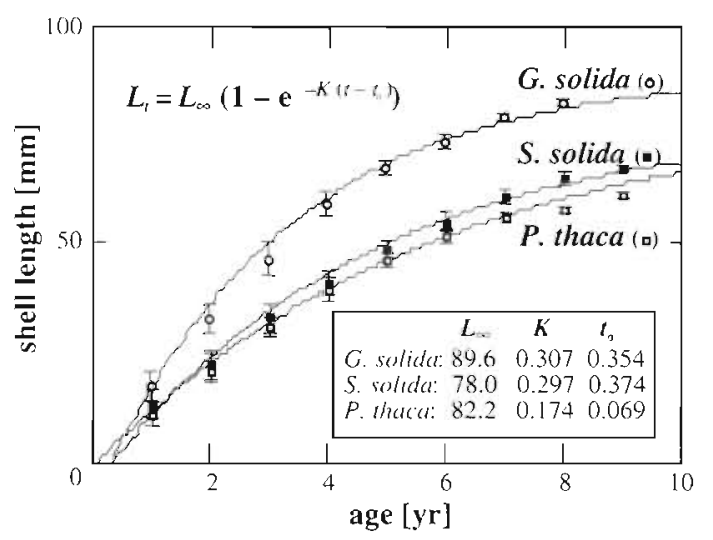

Fig. 3. Gari solida, Semele solida and Protothaca thaca. Nonoscillating growth curves of the von Bertalanffy growth function (VBGF) and age-length data of 3 Chilean bivalve species. VBGF parameters (asymptotic length, $L$; growth constant, $K$; age at zero length, $t_{0}$ ) are given in the inset. Vertical bars indicate standard deviations of the mean lengths

Table 2. Gari solida, Semele solida and Protothaca thaca. Von Bertalanffy growth function (VBGF) parameters of 3 Chilean bivalve species estimated from 2 data sets: tagging-recapture data (with Fabens method) and age-length data (with the VBGF and the Simplex algorithm). $L_{\infty}$ : asymptotic length $(\mathrm{mm}) ; K$ : growth constant $\left(\mathrm{yr}^{-1}\right) ; t_{0}$ : age at zero length

\begin{tabular}{|c|c|c|c|c|c|c|c|c|c|}
\hline Species & $L_{\infty}$ & $K$ & $t_{0}$ & $r^{2}$ & $L^{a}$ & $K^{\mathrm{b}}$ & $t_{0}^{b}$ & $r^{2}$ & $\mathrm{n}$ \\
\hline \multicolumn{10}{|c|}{ Tagging-recapture data } \\
\hline G. solida & 86.1 & 0.349 & - & 0.96 & 89.6 & 0.319 & - & 0.95 & 8 \\
\hline S. solida & 85.3 & 0.187 & - & 0.98 & 78.0 & 0.219 & - & 0.99 & 9 \\
\hline P. thaca & 70.0 & 0.253 & - & 0.99 & 82.2 & 0.184 & - & 0.98 & 9 \\
\hline \multicolumn{10}{|c|}{ Age-length data } \\
\hline G. solida & 106.3 & 0.193 & 0 & 0.95 & 89.6 & 0.295 & 0.354 & 0.99 & 51 \\
\hline S. solida & 100.6 & 0.127 & 0 & 0.99 & 78.0 & 0.213 & 0.374 & 0.99 & 89 \\
\hline P. thaca & 78.7 & 0.174 & 0 & 0.98 & 82.2 & 0.164 & 0.069 & 1.00 & 109 \\
\hline
\end{tabular}




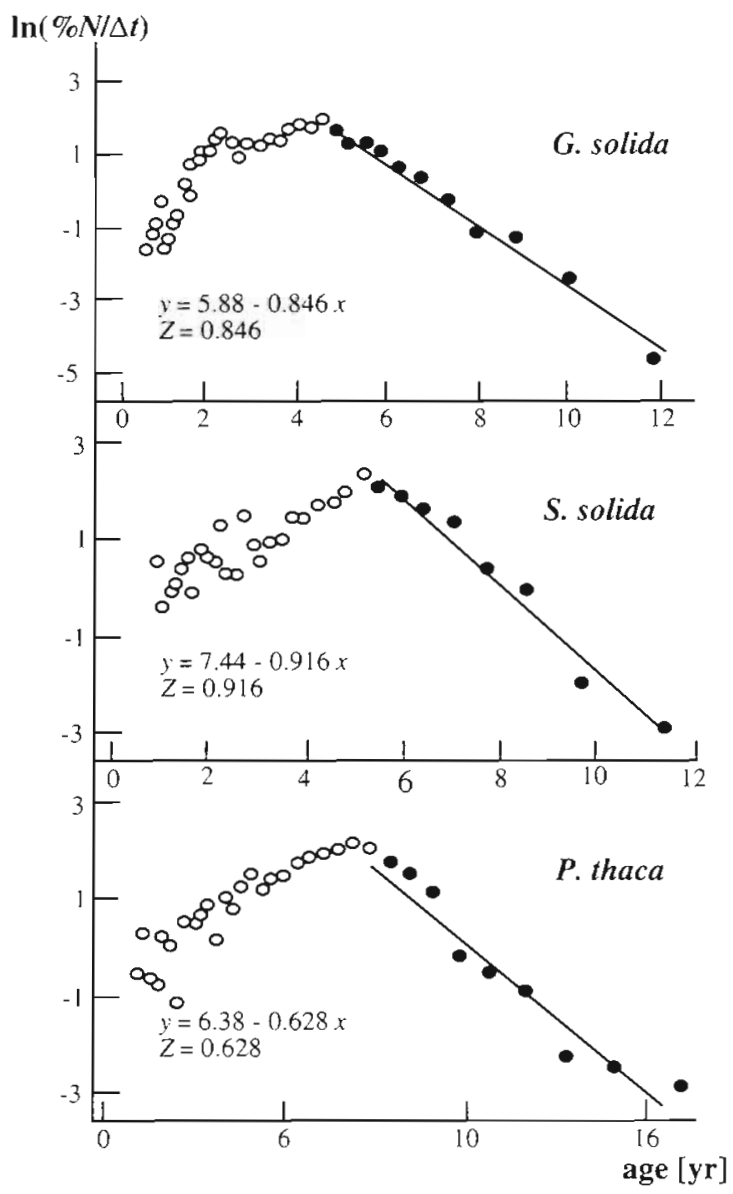

Fig. 4. Gari solida, Semele solida and Protothaca thaca. Length-converted catch curves of 3 Chilean bivalve species based on pooled length-frequency samples (from April 1991 to March 1992) and calculated with the ELEFAN II program. The VBGF parameters $L_{\infty}, K$ and $t_{0}$ required for this method are given in Table 3 . Solid symbols: used for calculations of $Z$ (mortality); open symbols: excluded from calculations. Linear regression equation and estimated $Z$-values are given

\section{Production}

The parameters of the linear regression analysis of the length-weight (AFDW) relationship used for the calculation of somatic production are given in Table 4 . Individual somatic and gonad production of Gari solida and Semele solida follow a similar pattern (Fig. 5). Somatic production increases to its highest value at 50 to $55 \mathrm{~mm}$ length ( $G$. solida $\sim 1.0$ and $S$. solida $\sim 0.4 \mathrm{~g}$ AFDW ind. ${ }^{-1} \mathrm{yr}^{-1}$ ) and decreases thereafter. Gonad production begins at 20 to $25 \mathrm{~mm}$ length at a level little below somatic production, increasing exponentially and exceeds somatic production at $45 \mathrm{~mm}$ length. Its highest values are $\sim 4.0 \mathrm{~g}$ AFDW ind.$^{-1} \mathrm{yr}^{-1}$ at $85 \mathrm{~mm}$ for G. solida and $\sim 1.0 \mathrm{~g} \mathrm{AFDW} \mathrm{ind} .^{-1} \mathrm{Yr}^{-1}$ at $75 \mathrm{~mm}$ for S. solida. Somatic production of Protothaca thaca
Table 4. Gari solida, Semele solida and Protothaca thaca. Parameters of the length ( $\mathrm{mm}$ ) to ash-free body dry weight (g) relationship for 3 Chilean bivalve species. $\log ($ AFDW $)=$ $a+b \log ($ Length $)$

\begin{tabular}{lcccc}
\hline Species & $a$ & $b$ & $\mathrm{r}^{2}$ & $\mathrm{n}$ \\
\hline G. solida & -4.659 & 2.837 & 0.96 & 35 \\
S. solida & -5.032 & 3.004 & 0.95 & 34 \\
P. thaca & -6.020 & 3.658 & 0.97 & 32 \\
\hline
\end{tabular}

reaches its highest level at $60 \mathrm{~mm}$ length $(-0.6 \mathrm{~g}$ AFDW ind.$\left.^{-1} \mathrm{yr}^{-1}\right)$. Gonad production of this species follows the curve of somatic production, reaching its highest values at $60 \mathrm{~mm}$ length with $0.7 \mathrm{~g}$ AFDW ind.- ${ }^{-1}$ $\mathrm{yr}^{-1}$. Contrasting to the latter 2 species, gonad production of $P$. thaca does not increase exponentially.

The distribution of annual somatic and gonad production and the abundance among the length classes

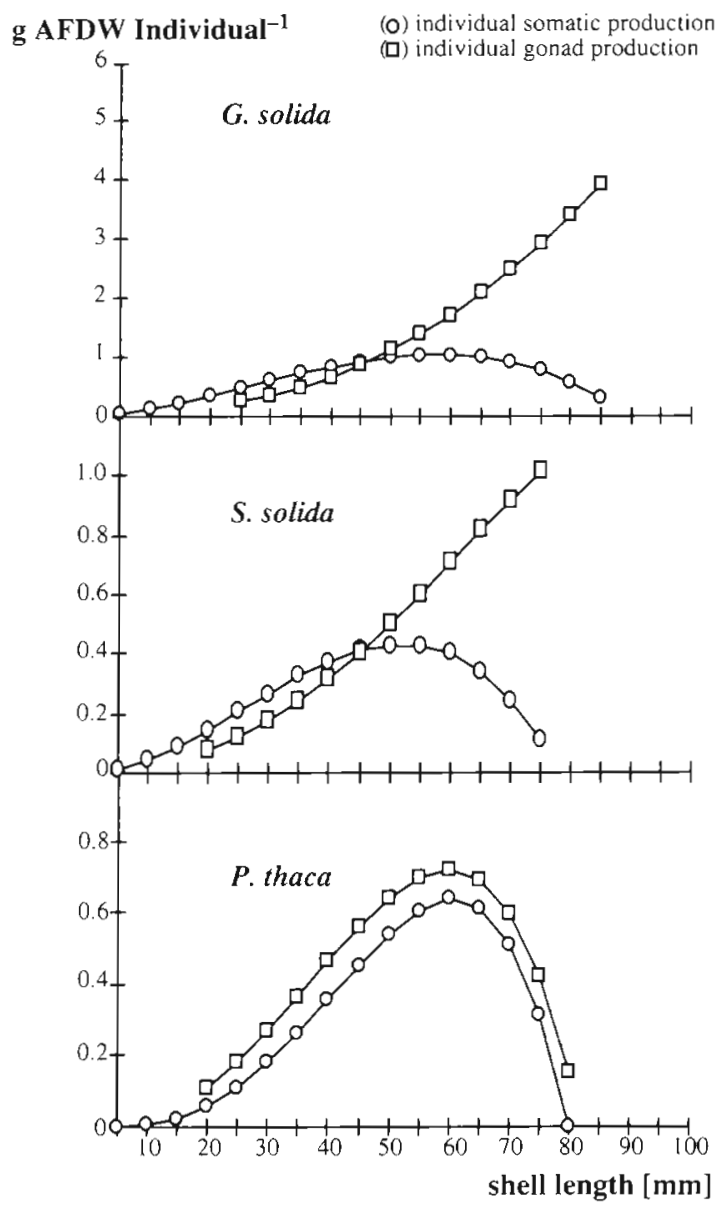

Fig. 5. Gan solida, Semele solida and Protothaca thaca. Individual production of somatic tissues and individual gonad production for different length classes of 3 Chilean bivalve species 


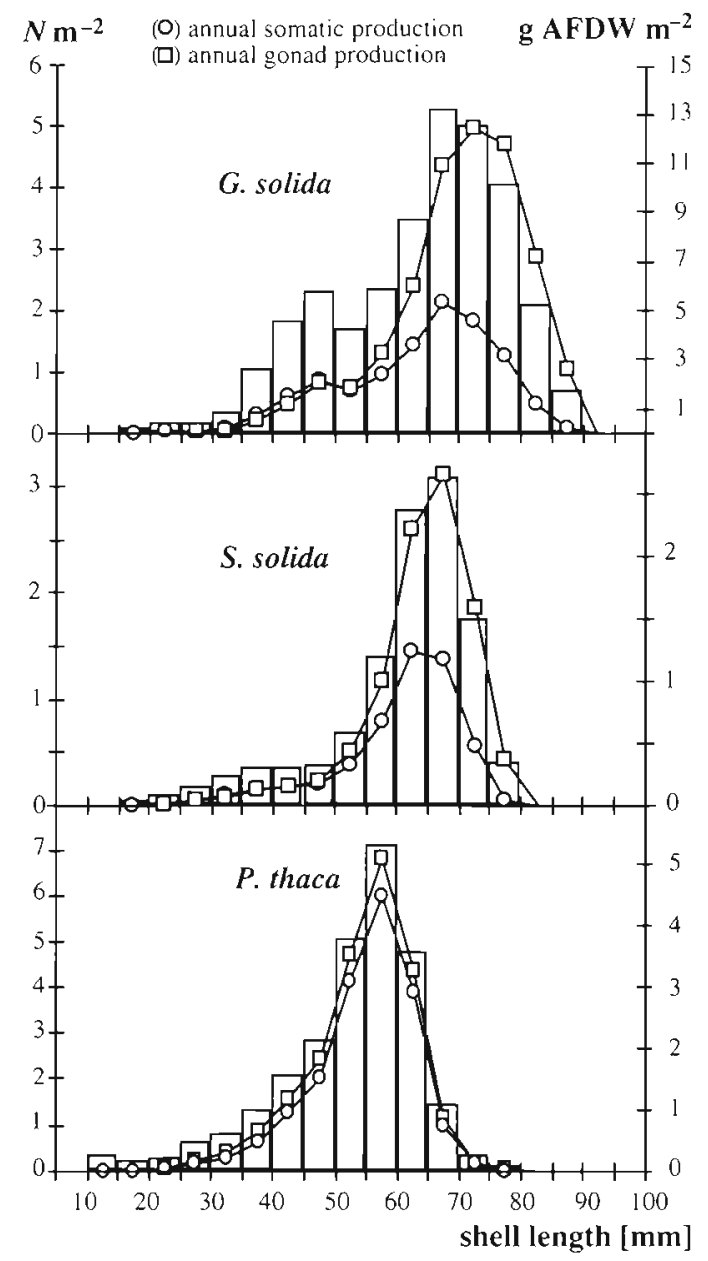

Fig. 6. Cari solida, Semele solida and Protothaca thaca Distribution of annual production of somatic tissues, annual gonad production and mean abundance for different length classes of 3 Chilean bivalve species

are shown in Fig. 6. The length-frequency distribution indicates a unimodal distribution for Semele solida and Protothaca thaca in the range of the higher length classes ( $S$. solida: 55 to $75 \mathrm{~mm}, P$. thaca: 50 to $65 \mathrm{~mm}$ ). Only for Gari solida do 2 modes seem to exist (35 to 55 and 55 to $85 \mathrm{~mm}$ ). However, all 3 populations seem to

Table 5. Gari solida, Semele solida and Protothaca thaca. Summary of pro duction estimation for 3 Chilean bivalve species

\begin{tabular}{|c|c|c|c|}
\hline & G. solida & S. solida & P. thaca \\
\hline Annual gonad production (g AFDWm ${ }^{-2}$ ) & 56.0 & 8.6 & 14.5 \\
\hline Annual somatic production (g AFDW m ${ }^{-2}$ ) & 27.6 & 4.8 & 16.9 \\
\hline Annual biomass (g AFDW m ${ }^{-2}$ ) & 82.6 & 25.5 & 62.9 \\
\hline Annual $P / \bar{B}$ ratio & 0.334 & 0.188 & 0.269 \\
\hline Mean abundance $\left(\mathrm{n} \mathrm{m}^{-2}\right)$ & 30.7 & 13.3 & 27.3 \\
\hline Mean body weight (g AFDW) & 2.69 & 1.91 & 2.30 \\
\hline
\end{tabular}

consist mainly of old adult individuals with a small number of recruits. The annual production estimates are given in Table 5. Annual somatic production and mean biomass of $G$. solida amount to the highest values of all 3 species studied $\left(27.6\right.$ and $82.6 \mathrm{~g} \mathrm{AFDW} \mathrm{m}^{-2}$ $\mathrm{yr}^{-1}$ ), followed by $P$. thaca (16.9 and $62.9 \mathrm{~g} \mathrm{AFDW} \mathrm{m}^{-2}$ $\mathrm{yr}^{-1}$ ) and finally $S$. solida $\left(4.8\right.$ and $25.5 \mathrm{~g} \mathrm{AFDW} \mathrm{m}^{-2}$ $\left.\mathrm{yr}^{-1}\right)$. Annual gonad production approximately doubles somatic production in $G$. solida and $S$. solida $(56.0$ and $8.7 \mathrm{~g} \mathrm{AFDW} \mathrm{m}^{-2} \mathrm{yr}^{-1}$, respectively), while for $P$. thaca it almost equals somatic production $(14.5 \mathrm{~g}$ AFDW $\mathrm{m}^{-2} \mathrm{yr}^{-1}$ ). The following $P / \bar{B}$ ratios were calculated: $G$. solida $=0.334$, S. solida $=0.188$, P. thaca $=$ 0.269 .

\section{DISCUSSION}

\section{Reproduction}

Ishiyama \& Chávez (1990) studied the reproduction cycle of Gari solida from Pisco, Peru (14 $4^{\circ}$ ) based on histological sections. They found a biannual cycle with reproductive activities in spring (October/ November) and late summer (February/March) related to the annual temperature cycle, stating for $G$. solida continuous and synchronous gonad activities during the whole year. After each spawning cycle gonads recuperate rapidly to begin a new reproductive cycle. Campos et al. (1993) reported a continuous gametogenesis with several reproductive cycles and spawning events per year for Semele solida from Tongoy, Chile $\left(30^{\circ} \mathrm{S}\right)$. Henríquez et al. (1981) found similar continuous and synchronous gonad activities for Protothaca thaca from San Jorge Bay, Chile $\left(23^{\circ} \mathrm{S}\right)$ with spawning activities in August, February, March and May. These findings seem to contradict our own results which clearly indicate an annual reproductive cycle with a short spawning period in summer and a longer resting period in winter.

The examples for a continuous or biannual reproductive cycle were found in northern latitudes, nearer to the equator, while our own research area is located more towards the south $\left(37^{\circ} \mathrm{S}\right)$. Towards the south, annual ambient conditions during winter become unfavourable, thus, spawning seasons have to become shorter and can change from biannual to annual. Chaparro \& Winter (1983), citing Lozada (1968), found a short spawning season during spring and summer and a longer resting period in winter for the mytiloid species Aulacomya ater, from Putemún, Chile, and Mytilus chilensis from Chiloe, Chile $\left(43^{\circ} \mathrm{S}\right)$, Similar exam- 
ples for annual reproductive cycles and spawning in summer are also available for clams from the NorthAmerican Pacific coast. Protothaca staminea from British Columbia, Canada ( $48^{\circ} 57^{\prime} N$ ) spawns between May and September (Quayle 1943) and those from

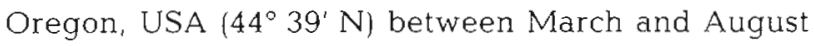
(Robinson \& Breese 1982) while Clinocardium nuttallii from Washington, USA $\left(48^{\circ} 35^{\prime} \mathrm{N}\right)$ spawns between July and November (Gallucci \& Gallucci 1982). Thus, latitudinal effects and unfavourable ambient conditions related to them could explain the different reproductive strategies of the populations cited above. In contrast, Lozada \& Bustos (1984), who studied the reproduction of Venus antiqua (which is closely related to $P$. thaca) from Chiloe, Chile $\left(43^{\circ} \mathrm{S}\right.$, only $6^{\circ}$ more to the south than our own research area), also found biannual reproductive (and body weight) cycles similar to those of the 3 populations cited above. It therefore seems that the explanation stated above is not generally the rule. Species-specific differences or locally different ambient conditions (e.g. currents, upwellings, nutrients) could dominate over a possible general latitudinal pattern. Clasing et al. (1994) explained the very high annual somatic production of $V$. antiqua from Chiloe by a comparatively long period of high primary production as well as the high nutritional value of suspended organic matter.

\section{Growth and mortality}

Urban (1991) estimated the growth of Gari solida and Semele solida from Pisco, Peru $\left(14^{\circ} \mathrm{S}\right)$. He found the following VBGF parameters: $G$. solida, $L_{\infty}=86 \mathrm{~mm}, K=$ $0.72 \mathrm{yr}^{-1}$; and $S$. solida, $L_{\infty}=85 \mathrm{~mm}, K=0.48 \mathrm{yr}^{-1}$. The $L_{\infty}$-values agree well with the own values presented here while the $K$-values are much higher. However water temperatures are about $5^{\circ} \mathrm{C}$ higher than in Chile (Urban 1994) and ambient conditions sustain a biannual reproduction cycle (see above), therefore, higher $K$-values can be expected in Peru. Vega (1979) studied the growth of Protothaca thaca in the Bay of Concepción, Chile $\left(37^{\circ} \mathrm{S}\right)$, very close to our own research area. His final (corrected) values are $L_{\infty}=95.3 \mathrm{~mm}$ and $K=$ $0.16 \mathrm{yr}^{-1}$, owing to his assumption that 2 growth rings were formed per year. However, the present resuits did not confirm this assumption. His uncorrected values ( $\left.L_{\mathrm{co}}=80.7 \mathrm{~mm}, K=0.29 \mathrm{yr}^{-1}\right)$ agree better with our own results. Comparing the growth of the 3 species indicates higher growth $\left(K \approx 0.3 \mathrm{yr}^{-1}\right)$ for $G$. solida and $S$. solida and slower growth $(K=0,17)$ for $P$. thaca. Taking into account the uncorrected $K$-value of Vega (1979) may indicate a similar growth for $P$. thaca as for the other 2 species. So far, no explanation for the different $K$-values of $P$. thaca is available.
Mortality values $(Z)$ are highest for Semele solida $(Z$ $\left.=0.92 \mathrm{yr}^{-1}\right)$, followed by Gari solida $\left(Z=0.84 \mathrm{yr}^{-1}\right)$ and lowest for Protothaca thaca $\left(Z=0.58 \mathrm{yr}^{-1}\right)$. During the study period the 3 populations found at the sampling site were not exploited intensively. Only a few local fishermen were observed at irregular intervals to collect individuals for consumption in the nearby village. Different $Z$-values could be explained by selection: $G$. solida and $S$. solida are collected more at the sampling site than $P$. thaca because a larger population of Venus antiqua is exploited more intensively only $1000 \mathrm{~m}$ away (the fishermen do not distinguish between $P$. thaca and $V$. antiqua, which are morphologically very similar).

\section{Production}

To the authors' knowledge, no other production estimates for the 3 species studied here exist so far. Clasing et al. (1994) estimated somatic and gonad production of Venus antiqua from Chiloe, Chile $\left(42^{\circ} \mathrm{S}\right) . \mathrm{V}$. antiqua is a shallow-water infaunal bivalve closely related and morphologically very similar to Protothaca thaca. Although Clasing et al. (1994) recorded a higher biomass they found an annual gonad production of only $2.0 \mathrm{~g} \mathrm{AFDW} \mathrm{m}^{-2} \mathrm{yr}^{-1}$ which is considerably lower than our own results $\left(56.0,8.6\right.$ and $14.5 \mathrm{~g} \mathrm{AFDW} \mathrm{m}^{-2}$ $\mathrm{yr}^{-1}$, respectively). Clasing et al. (1994) assumed only 1 spawning period per year. According to Lozada \& Bustos $(1984), V$. antiqua has a biannual reproductive cycle, thus, their reproductive output could have been underestimated by $50 \%$. In contrast to our 3 populations (Fig. 6), the amount of small individuals in the $V$. antiqua population from Chiloe is high. These young individuals devote most of their energy to somatic production and little to gonad production, which would be a further explanation for the low value of gonad production of $V$. antiqua. Finally, the method for gonad production applied in this study is based on weight changes before and during the spawning season. It is thereby assumed that all material stored during the weight increase in summer is devoted to reproduction. As this assumption is not correct - energy is devoted to growth and maintenance - the present gonad production is probably overestimated

In Fig. 7 our own results on annual somatic production are compared with data found in the literature on other Tellinacea and Veneracea by plotting the $P / \bar{B}$ ratio against the mean body weight. It can be seen clearly that our own data (1) agree very well with the data taken from the literature and (2) are in the lower range of the $P / \bar{B}$ data presented. As stated above, only a small number of recruits were present during the study period. Thus, the 3 populations consist of older 
Fig. 7. Comparison of somatic production of 3 Chilean bivalve species, Gari solida (Gs), Semele solida (Ss) and Protothaca thaca (Pt) with other species of the superfamilies Veneracea and Tellinacea (taken from the literature) by plotting the $P / \bar{B}$ ratio against mean body weight (MBW).

Literature sources:

(Va) Venus antiqua, Chiloe, Chile (Clasing et al. 1994)

1: Donax vittatus, South Wales, UK (Warwick et al. 1978)

3: Scrobicularia plana, Cornwall, UK (Warwick \& Price 1975)

4, 5: Abra alba, Kiel Bight, Germany (Rainer 1985)

6-10: Abra alba, English Channel, France (Dauvin 1986)

11. Abra nitida, Northumberland, UK (Buchanan \& Warwick 1974)

12, 13: Abra nitida, North Sea, Sweden (Josefson 1982)

15: Macoma balthica, Nova Scotia, Canada (Burke \& Mann 1974)

16, 17: Macoma balthica, North Sea, Denmark (Madsen \& Jensen 1987)

18: Macoma balthica, Cornwall, UK (Warwick \& Price 1975)

19, 20: Macoma calcarea, Arctic Sea, Greenland (Petersen 1978)

21-28: Tellina fabula, German Bight, Germany (Salzwedel 1980)

29, 30: Tellina fabula, Yorkshire, UK (Rees 1983)

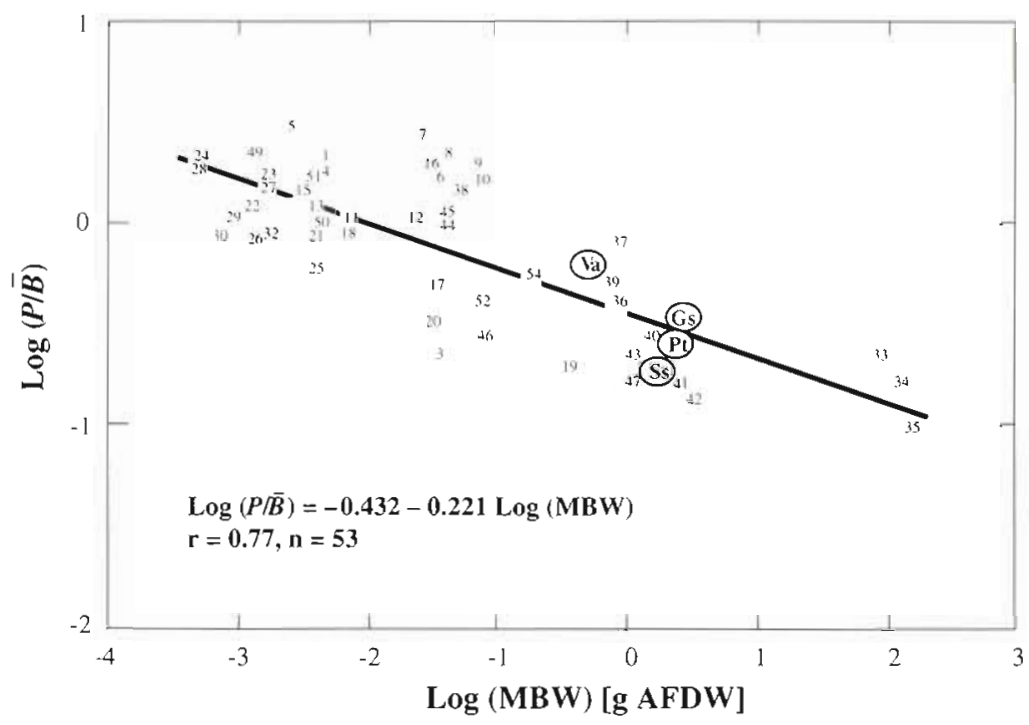

31: Tellina fabula, South Wales, UK (Warwick et al. 1978)

33-35: Callista brevisiphonata, Sea of Japan, Russia (Selin \& Selina 1988)

36, 37: Chione cancellata, Florida, USA (Moore \& Lopez 1969)

38: Dosinia elegans, Florida, USA. (Moore \& Lopez 1970)

39-41: Mercenaria mercenaria Southampton, UK (Hibbert 1976)

42, 43: Mercenaria mercenaria, Geor- gia, USA (Walker \& Tenore 1984)

44-46: Venerupis aurea, Southampton, UK (Hibbert 1976)

47. Venerupis pullastra, North Sea, Norway (Johannessen 1973)

49-51: Venus ovata, English Channel, France (Dauvin 1985)

52: Venus striatula, South Wales, UK (Warwick et al. 1978)

54: Pharus legumen, South Wales, UK (Warwick et al. 1978) individuals with low somatic production. Accordingly, the $P / \vec{B}$ ratio of Venus antiqua from Chiloe in Fig. 7, a population of younger individuals with high somatic production, is located more towards the upper $P / \bar{B}$ and the lower mean body range.

The different findings on somatic production in Dichato and Chiloe could be caused by different exploitation rates in the fisheries. Hall et al. (1970) showed that after fish predation in a freshwater pond increased, only benthic production increased while its biomass remained constant. Fish consumed only the large individuals from the benthic population and consequently the $P / \bar{B}$ ratio increased. In the case of the clam fisheries the situation is similar: mainly clams with a certain minimum (marketable) size are collected for consumption. Clasing et al. (1994) reported a high fishing pressure for the Venus antiqua population from Chiloe, which altered the size structure towards younger individuals with high somatic production and $P / \bar{B}$ ratio.

Acknowledgements. This study was financed by the 'El Niñoproject' of the Alfred Wegener Institute. The Dean of the 'Departamento de Oceanología, Universidad de Concepción', Concepción (Chile) kindly permitted the use of facilities. Our thanks are expressed to the scientific and technical staff of the University of Concepción for most friendly and helpful support. Thanks also to M.Sc. Teresa Jeri for her diving assistance and for carrying out some of the samplings, as well as to Dr Thomas Brey for some helpful advice.

\section{LITERATURE CITED}

Bertalanffy, von, L. (1938). A quantitative theory of organic growth (inquiries on growth laws II). Hum. Biol. 10(2): $181-213$

Beverton, R. J. H., Holt, S. J. (1956). A review of methods for estimation mortality rates in exploited fish populations, with special reference to sources of bias in catch sampling. Rapp. P.-v. Réun. Cons. int. Explor. Mer 140:67-83

Buchanan, J. B., Warwick, R. M. (1974). An estimation of benthic macrofaunal production in the offshore mud of the Northumberland Coast. J. mar. biol. Ass. U.K. 54: 197-222

Burke, M. Mann, K. H. (1974). Productivity and production: biomass ratios of bivalve and gastropod populations in an Eastern Canadian estuary. J. Fish. Res. Bd Can. 31(2): $167-177$

Campos, B., Guerra, R., Bellolio, G. (1993). Bases biotecnológicas para la producción masiva de juveniles de almejas de importancia económica. Informe final, Proyecto de Investigación 502-91, Fondo Nacional de Investigación Científica y Tecnológica, CONICYT Universidad de Valparaíso, Viña del Mar

Chaparro, O. R., Winter, J. (1983). Efectos de una pobre oferta alimentaria en Mytilus chilensis sobre el crecimiento, 
reproducción y standing stock en la mylticultura de Yaldad (Chiloe, Sur de Chile). Mem. Asoc. Latinoam. 5(2): 203-214

Clasing, E., Brey, T., Stead, R., Navarro, J., Asenico, G. (1994). Population dynamics of Venus antiqua (Bivalvia: Veneracea) in the Bahía de Yaldad, Isla de Chiloé, Southern Chile. J. exp. mar. Biol. Ecol. 177: 171-186

Crisp, D. J. (1984). Energy flow measurements. In: Holme, N. A., McIntyre, A. D. (eds.) Methods for the study of marine benthos. Blackwell, London, p. 284-372

Dauvin, J.-C. (1985). Dynamique et production d'une population de Venus ovata (Mollusque-Bivalve) de la Baie de Morlaix (Manche Occidentale). J. exp. mar. Biol. Ecol. 91: $109-123$

Dauvin, J.-C. (1986). Biologie, dynamique et production d'une population d'Abra alba (Wood) (Mollusque-Bivalve) de la Baie de Morlaix (Manche Occidentale). J. exp. mar. Biol. Ecol. 97. 151-180

Eversole, A. G. (1989). Gametogenesis and spawning in North American clam populations: implications for culture. In: Mauzi, J. J., Costagna, M. (eds.) Clam mariculture in North America. Dev. Aquacult. Fish. Sci. 19: 75-109

Fabens A. J. (1965). Properties and fitting of the von Bertalanffy growth curve. Growth 29: 265-285

Gallucci, V. F., Gallucci, B. B. (1982). Reproduction and ecology of the hermaphroditic cockle Clinocardium nuttallii (Bivalvia: Cardiidae) in Garrison Bay. Mar. Ecol. Prog. Ser. 7: $137-145$

Gayanilo, F. C., Soriano, M., Pauly, D. (1988). A draft guide to the Compleat ELEFAN. ICLARM Software 2, ICLARM Contribution No. 435. ICLARM, Manila

Hall, D. J., Cooper, W. E., Werner, E. E. (1970). An experimental approach to the production dynamics and structure of freshwater annual communities. Limnol. Oceanogr. 15: $839-928$

Henríquez, R., Barboza, P., Taipa, E., Toro, C. (1981). Variación anual de la gónada de la almeja Protothaca thaca (Molina, 1782): análisis histológico. Resum. Jorn. Cienc. Mar 34

Hibbert, C. J. (1976). Biomass and production of a bivalve community on an intertidal mud-flat. J. exp. mar. Biol Ecol. 25: 249-261

Ishiyama, C. V. Chávez, G. (1990). Reproducción de Gari solida (Veneroida, Psammobidae). Rev. Ciencias U.N.M.S.M. $75(1): 52-65$

Johannessen, O. H. (1973). Length and weight relationship and the potential production of the bivalve Venerupis pullastra (Montagu) on a sheltered beach in Western Norway. Sarsia 53: 41-48

Josefson, A. B. (1982). Regulation of population size, growth and production of a deposit-feeding bivalve: a long-term field study of three deep-water populations off the Swedish west coast. J. exp. mar. Biol. Ecol. 59: 125-150

Lozada, E. (1968). Contribución al estudio de la cholga Aulacomya ater en Putemún. Biol. Pesq. Chile 3:3-39

Lozada, E., Bustos, H. (1.984). Madurez sexual y fecundidad de Venus antiqua (King \& Broderip, 1835), en la bahia de Ancud (Mollusca: Bivalvia: Veneridae). Rev. Biol. mar. Valparaiso 20: $91-112$

Lucas, A. (1971). Les gamètes des mollusques. Haliotis 1(2): $185-214$

Madsen, P. B., Jensen, K. (1987). Population dynamics of Macoma balthica in the Danish Wadden Sea in an organically enriched area. Ophelia 27 (3): 197-208

Moore, H. B., Lopez, N. N. (1969). The ecology of Chione can- cellata. Bull. mar. Sci. 19: 131-148

Moore, H. B., Lopez, N. N. (1970). A contribution to the ecology of the lamellibranch Dosinia elegans. Bull. mar. Sci. 20: $980-986$

Pauly, D. (1979). Gill size and temperature as governing factors in fish growth: a generalization of von Bertalanffy's growth formula. Ber. Inst. Meereskde, Kiel 63: 1-156

Pauly, D. (1986). On improving operation and use of the ELEFAN programs. Part II. Improving the estimation of $L_{\infty}$. Fishbyte 4(1): $18-20$

Peterson, G. H. (1978). Life cycles and population dynamics of marine benthic bivalves from the Disko Bugt Area of West Greenland. Ophelia 17(1): 95-120

Quayle, D. B. (1943). Sex, development and seasonal gonad changes in Paphia staminea Conrad. J. Fish. Res. Bd Can. 6(2): $140-151$

Rainer, S. F. (1985). Population dynamics and production of the bivalve Abra alba and implications for fisheries production. Mar. Biol. 85: 253-262

Raven, C. P. (1961). Oogenesis. The storage of developmental information. Pergamon Press, New York

Rees, H. L. (1983). Pollution investigations off the north-east coast of england: community structure, growth and production of benthic macrofauna. Mar. environ. Res. 9 $61-110$

Robinson, A. M., Breese, W. P. (1982). The spawning season of four species of clams in Oregon. J. Shellfish Res. 2(1) $55-57$

Ryther, J. H. (1969). Photosynthesis and fish production in the sea. Science 166: $72-76$

Salzwedel, H. (1980). Energy budgets for two populations of the bivalve Tellina fabula in the German Bight. Veröff. Inst. Meeresforsch. Bremerh. 18: 257-287

Selin, N. I., Selina, M. S. (1988). Production characteristics of the bivalve mollusk Callista brevisiphonata in Peter the Great Bay, Sea of Japan. Soviet. J. mar. Biol. 14(4): $219-223$

Urban, H.-J. (1991). Preliminary estimates of growth parameters for three commercial bivalve species of Peru (Gari sol. ida, Aulacomya ater and Semele solida). Fishbyte 9: 4-6

Urban, H.-J. (1992). Ökologie ökonomisch wichtiger Muschelarten im Auftriebssystem der Pazifikküste Lateinamerikas. Dissertation, Universität Bremen

Urban, H.-J. (1994a). Upper temperature tolerance of ten bivalve species off Peru and Chile related to El Niño. Mar. Ecol. Prog. Ser. 107: 139-145

Urban, H.-J. (1994b). Adaptation of six infaunal bivalve species of Chile: coexistence resulting from differences in morphology, burrowing depth and substrate preference Arch. Fish. mar. Res. 42(2): in press

Vega, R. E. (1979). Algunos aspectos de la biología de la almeja común Protothaca thaca (Molina, 1782), en la Bahia de Concepción, Chile. Tesis para optar al titulo de biologo marino, Universidad de Concepción

Walker, R. L., Tenore, K. R. (1984). The distribution and production of the hard clam, Mercenaria mercenaria, in Wassaw Sound, Georgia. Estuaries 7(1): 19-27

Warwick, R. M., Price, R. (1975). Macrofauna production in an estuarine mud-flat. J. mar. biol. A.ss. U.K. 55: 1- 18

Warwick, R. M., George, C. L., Davies, J. R. (1978). Annual macrofauna production in a Venus community. Estuar. coast. mar. Sci, 7: 215-241

Wetherall, J. A. (1986). A new method for estimating growth and mortality parameters from length-frequency data. Fishbyte $4(1): 12-14$

Manuscript first recelved: April 29,1994

Revised version accepted: September 22, 1994 